\title{
Measurement of bacterivory by heterotrophic nanoflagellates using immunofluorescence labelling of ingested cells
}

\author{
Kirsten Christoffersen ${ }^{1, *}$, Ole Nybroe ${ }^{2}$, Klaus Jürgens ${ }^{3}$, Michael Hansen ${ }^{2}$ \\ ${ }^{1}$ Freshwater Biological Laboratory, University of Copenhagen, Helsingersgade 51, DK-3400 Hillerød, Denmark \\ ${ }^{2}$ Dept of Ecology and Molecular Biology, Royal Veterinary and Agricultural University, Thorvaldsensvej 40, DK-1958 Frederiksberg C, Denmark \\ ${ }^{3}$ Max-Planck-Institut für Limnologie, Dept of Ecophysiology, PO Box 165, D-24302 Plön, Germany
}

\begin{abstract}
A method based on fluorescent-antibodylabelled bacteria (FALB) was developed to demonstrate the presence of ingested bacteria in the food vacuoles of heterotrophic nanoflagellates. Individual bacterial cells are identified in the food vacuoles by immunofluorescence labelling using strain-specific antibodies after uptake of the live cells. The procedure includes permeabilization of fixed flagellate cells prior to the immunoreaction. The uptake of Pseudomonas fluorescens (strain ON2 and Ag1) and $P$. putida (strain MM1) by Spumella sp., Bodo saltans and 2 unidentified heterotrophic nanoflagellate species was tested. The ingested bacteria were visualized in the food vacuoles by epifluorescence and laser confocal scanning microscopy. The ability of the polyclonal antibodies to recognize the target bacteria was good and very few cross-reactions with other bacteria or other organic compounds were observed. A linear uptake of live bacteria was recorded during the first $15 \mathrm{~min}$ of the feeding period and immunolabelled remains of the bacteria were visible inside and around the food vacuoles after extended feeding periods. Ingestion rates measured by the FALB method were significantly higher than those measured by FLB which confirms conclusions from several recent studies using vial stains to detect grazing on bacteria. It was concluded that the FALB method is useful and suitable to examine feeding of protists on specific bacteria as well as differential uptake of bacteria within a mixture. The FALB method does not involve any manipulations of the bacterial cells before the feeding experiment and thus measures realistic ingestion rates.
\end{abstract}

KEY WORDS: Protists - Grazing · Bacteria - Immunofluorescence labelling

Since the recognition of the importance of the interactions between pelagic heterotrophic bacteria and their nanograzers (heterotrophic nanoflagellates and ciliates) in aquatic environments a large number of studies have been devoted to estimating the quantitative importance and ecological range of bacterivory

•E-mail: kcfbl@ibm.net
(Sherr \& Sherr 1994). A number of methods for measuring protist grazing on bacteria have been developed over the years (reviewed by Landry 1994). A widely applied approach is to determine the uptake of fluorescently labelled food particles directly by epifluorescence microscopy. Initially, the uptake of substitutes for biological food particles such as latex beads was studied (Børsheim 1984). Later, this approach was refined by using prey bacteria that had been labelled with fluorescent compounds through a staining procedure that killed the fluorescently labelled bacteria (FLB; Sherr et al. 1987).

Comparisons of grazing rates of FLB and live-stained bacteria have demonstrated that the latter are, in some cases, ingested at rates 10 to 20 times higher (Landry et al. 1991, Monger \& Landry 1992, González et al. 1993). These results indicate that FLB may be artificial to the grazers and that chemical and behavioral properties of the prey affect the feeding activity of some flagellates (Chrzanowski \& Simek 1990, González et al. 1990). Hence, live staining of bacteria represents a methodological improvement but the staining procedures still involve manipulations of the target cells prior to the grazing experiments, i.e. extended incubations with stain and exposure to organic solvents (Monger \& Landry 1992, González et al. 1993). Further, the estimation of grazing may suffer from insufficient labelling of the cells and/or subsequent loss of the stain (Epstein \& Rossel 1995). Consequently there is a need for methods to determine ingestion of bacteria that have not been subjected to any manipulations prior to the feeding experiment and that provide a stable labelling.

The purpose of this study was to develop a method to estimate protist grazing on live bacterial cells based on detection of ingested cells in the food vacuoles of the grazer by immunofluorescence microscopy. Fluorescent antibody techniques have been widely used for 
detection of specific bacterial strains in autecological studies but, to our knowledge, have not been used to demonstrate the intracellular occurrence of bacteria in protist grazers.

Materials and methods. Bacterial strains and protozoans: Pseudomonas fluorescens strains ON2 $\left(0.50 \mu \mathrm{m}^{3}\right)$ and $\mathrm{Ag} 1\left(0.91 \mathrm{\mu m}^{3}\right)$ and $P$. putida strain MM1 $\left(1.04{\left.\mu \mathrm{m}^{3}\right)}^{3}\right.$ were used as prey for protozoan grazers. Strain ON2 was isolated from freshwater sediment, strain Ag1 from soil and strain MM1 from barley rhizosphere. All 3 strains were isolated as fluorescent colonies on Kings $\mathrm{B}$ agar and subsequently identified by the API20NE system. The strains were grown on $10 \%$ tryptone soy agar (tryptone soy broth, TSB; DIFCO) containing $1 \%$ agar and harvested after $48 \mathrm{~h}$ at room temperature. Small inocula were suspended in $0.1 \%$ TSB and sonicated at $50000 \mathrm{~Hz}$ in cycles of $5 \mathrm{~min}$ until most aggregates were disrupted. The solutions were filtered through a $10 \mu \mathrm{m}$ nitex filter in order to remove remaining aggregates. The concentration of the bacteria was determined by epifluorescence microscopy after staining with 4',6-diamidino-2-phenylindole dihydrochloride (DAPI, Sigma) and the solutions were diluted to a suitable concentration $\left(10^{7}\right.$ to $10^{8}$ cells ml $\left.{ }^{-1}\right)$ with $0.1 \%$ TSB.

The heterotrophic protozoans Bodo saltans (Kinetoplastidae; 4 to $5 \mu \mathrm{m}$ in diameter) and Spumella sp. (Crysomonadida; 3 to $4 \mu \mathrm{m}$ in diameter), obtained from Flemming Ekelund, Zoological Institute, University of Copenhagen, Denmark, were grown in a wheat grain medium. Dense cultures were obtained by the addition of $0.1 \%$ TSB. Grazing experiments were performed while the cultures were in the late exponential growth phase. Two other protozoan cultures were raised from lake water and seawater by screening the water through a $20 \mu \mathrm{m}$ net and addition of $0.1 \%$ TSB. These cultures were also harvested in the late exponential growth phase. Both types of culture were grown in darkness at $18 \pm 1^{\circ} \mathrm{C}$.

Development of antibodies: The specificity and utility of the antibody to Pseudomonas fluorescens Ag1 have been published previously (Nybroe et al. 1990, Ahl et al. 1995). Polyclonal antibodies against ON2 and MM1 were prepared by immunizing rabbits (strain Ssc: $\mathrm{CPH}$, State Serum Institute, Copenhagen) with whole cells which had been incubated at $100^{\circ} \mathrm{C}$ for $2 \mathrm{~h}$. The antisera were absorbed and purified as described by Nybroe et al. (1990). The absorbed antibody preparations were found to be strain specific when tested in DOT-immunobinding analysis (Kragelund et al. 1996) against 26 strains of rRNA homology group I pseudomonads. Furthermore, cross reactions to bacteria indigenous to the water samples employed did not occur.

Grazing experiments: All grazing experiments were performed in the laboratory using subsamples of het- erotrophic nanoflagellate cultures. A grazing experiment consisted of triplicate samples of 5 or $10 \mathrm{ml}$ for each variable, i.e. time and food source. The bacterial suspensions were added by pipette and each sample was mixed gently before incubation at room temperature in darkness. The number of bacteria associated with the flagellate cultures was $<1 \times 10^{5} \mathrm{ml}^{-1}$ since the flagellates were harvested in the late exponential growth phase. The term 'bacterial concentration' refers to concentration of target bacteria in the experiments if not otherwise stated.

A set of experiments was performed in order to test the ability of the antibodies to detect ingested bacteria. Bodo saltans, Spumella sp. and an unidentified freshwater heterotrophic nanoflagellate species were fed live cells of Pseudomonas fluorescens ON2 or $P$. putida MM1 in separate time series experiments. Each experiment lasted for max. 30 min with several samplings during the period. The final bacterial concentrations were $5 \times 10^{6} \mathrm{ml}^{-1}$. The grazing experiments were terminated by adding $25 \%$ glutaraldehyde ( $1.5 \%$ final concentration) to the samples.

In a comparable set of experiments an unidentified marine nanoflagellate species was fed a combination of live cells and the corresponding FLB prepared from cultures of Pseudomonas fluorescens ON2 and P. putida MM1. These experiments lasted $40 \mathrm{~min}$. The final concentration of added bacterial cells (FALB, fluorescent-antibody-labelled bacteria, and FLB) was $4 \times 10^{6} \mathrm{ml}^{-1}$. Preparation of FLB followed the procedure described in Christoffersen (1994). Briefly, bacterial cultures were concentrated by reverse filtration before incubation with 5-(4,6-dichlorotriazin-2-yl) aminofluorescein (DTAF, Sigma) for $2 \mathrm{~h}$ at $50^{\circ} \mathrm{C}$. The labelled suspensions were centrifuged, washed 3 times with phosphate-buffered saline and sonicated for $5 \times 5 \mathrm{~min}$ at $50000 \mathrm{~Hz}$. The suspensions were filtered through a $5 \mu \mathrm{m}$ filter to remove large aggregates before calibration of numbers. Subsamples were stored refrigerated until use.

A final experiment was carried out to compare the concomitant uptake of 2 live bacterial stains. A culture of Spumella sp. received additions of Pseudomonas fluorescens Ag1 and P. putida MM1 in different ratios (by number) to obtain a final bacterial concentration of $3 \times 10^{6} \mathrm{ml}^{-1}$. The incubation period was $15 \mathrm{~min}$ and the samples were treated as described above.

Preparation of samples for immunofluorescence microscopy: Quantification of the Pseudomonas strains was performed by conventional immunofluorescence microscopy. Fixed samples were collected on $0.2 \mu \mathrm{m}$ polycarbonate membrane filters (Poretics, USA). The samples were filtered using low vacuum $(<0.2$ bar $)$ until all water had passed the filters. The filters were washed 3 times for $5 \mathrm{~min}$ with washing buffer $(50 \mathrm{mM}$ 
Tris/ $\mathrm{HCl}, 150 \mathrm{mM} \mathrm{NaCl}, 0.1 \%$ Tween $20,0.1 \%$ bovine serum albumin). After a $30 \mathrm{~min}$ incubation in blocking buffer (50 mM Tris/ $\mathrm{HCl}, 150 \mathrm{mM} \mathrm{NaCl}, 2 \%$ Tween 20 , $0.5 \%$ bovine serum albumin) the filters were washed as above. The strain-specific antibodies were diluted 1:500 in washing buffer and added to the samples which were incubated for $1.5 \mathrm{~h}$ in the dark. After a washing step, the filters were incubated with FITCconjugated swine-anti-rabbit immunoglobulins (DAKO, Denmark; diluted 1:40) for $1.5 \mathrm{~h}$ and washed again. The samples were finally stained with $2 \mu \mathrm{g} \mathrm{ml}^{-1}$ DAPI for $5 \mathrm{~min}$ and washed with distilled water. The filters were dried for approx. $1 \mathrm{~min}$ and then mounted on glass slides with No Fade mounting medium (Johnson $\&$ de Nogueira Araujo 1981). The slides were kept at $5^{\circ} \mathrm{C}$ for 1 to $2 \mathrm{~d}$ or otherwise frozen at $-20^{\circ} \mathrm{C}$ until microscopical analysis took place.

Immunochemical detection of bacterial cells after ingestion by protists was performed after permeabilization of flagellate membranes. We tested the effect of absolute ethanol diluted with distilled water (1:2), a methanol/acetone mixture (1:1) diluted with distilled water (1:2), and Triton X-100 (1\% final concentration) as permeabilizer of flagellate membranes. The solutions were added to membrane filters which contained glutaraldehyde-fixed flagellates. Incubation times were $1 \mathrm{~min}$ for the organic solvents and $2 \mathrm{~min}$ for Triton $X-100$. Furthermore, it was determined whether the repeated washing and incubation steps of the immunostaining procedure (see above) destroyed the protist cells. The solutions in question (blocking buffer and washing buffer) were tested by comparing the actual number of flagellates from samples that had been prepared using a conventional DAPI staining procedure with those that had been through repeated incubations and washing steps. These tests were carried out in triplicates using Bodo saltans as test organism.

Microscopy: The filters were inspected by epifluorescence microscopy (Olympus $\mathrm{BH} 2$ ) at $1250 \times$ magnification. Between 75 and 200 flagellates were inspected per filter. The microscopes were equipped with an ultraviolet (405 $\mathrm{nm}$ ) and blue filter set $(490 \mathrm{~nm})$. The flagellates were identified under UV excitation by their nucleus which was stained with DAPI. The FALB in food vacuoles fluoresced yellow-green under blue excitation. A barrier filter $(475 \mathrm{~nm})$ efficiently removed autofluorescence.

In some cases a confocal scanning microscope (TCS4d, Leica) was used for the detection of the bacteria inside the flagellates. In contrast to conventional fluorescence microscopes this instrument only registers light emitted from the focal plane. Consequently, the exact vertical position of the bacteria can be determined. The microscope was equipped with an Argon
Kryton laser and 2 photomultipliers. The objective was Leica $100 \times$ plan apo/1.4-0.7 oil. The microscope settings ensured that the FALB were detected at the first photomultiplier and the autofluorescence from the flagellate at the second. One recording from one photomultiplier consisted of a stack of 6 to 8 images reaching from top to bottom of the flagellate.

Calculations: The uptake of bacterial cells was calculated from the sum of ingested cells divided by the number of flagellates inspected (i.e. flagellates with and without ingested bacteria). The clearance rates were calculated from the uptake experiments by linear regression of data points until the first point of maximum uptake was recorded. There was no correction for the time zero background.

Results. Permeabilization and incubation procedures: Immunochemical detection of bacterial cells after ingestion by protists requires that the membranes (cell membrane and food vacuole membrane) of the grazer can be made permeable to the antibodies. Initially, it was determined if different permeabilization methods could be applied to flagellate cells without causing cell disintegration. Permeabilization with Triton X-100 and an ethanol-water mixture could be obtained without destroying the cells of Bodo saltans while treatment with acetone/methanol led to a significant ( $t$-test, $p<0.001$ ) reduction in cell numbers (Fig. 1). Furthermore, the treatment with Triton X-100 led to an improved detectability of the flagellates, probably due to an enhanced clarity of the material on the filters, and provided a more even distribution of particles. Permeabilization with Triton X-100 was

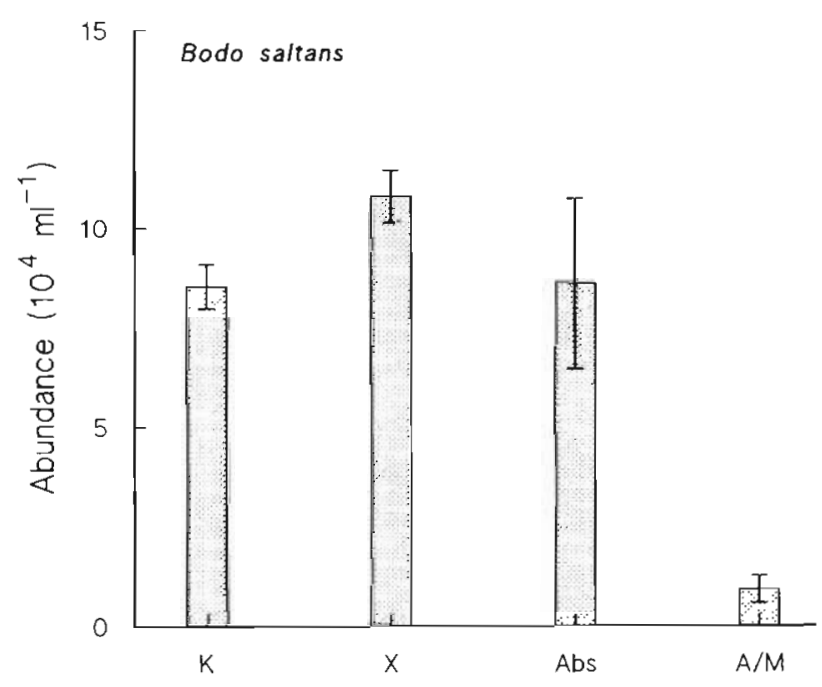

Fig. 1. Effects of no treatment $(K)$, Triton $X-100(X)$, absolute ethanol/water mixture (Abs) and acetone/methanol/water mixture (A/M) on the abundance of glutaraldehyde-fixed and DAPI-stained Bodo saltans. Values are means of triplicate samples. Bars are the standard deviation (SD) of the mean 
therefore carried out prior to the incubations with antibodies to detect ingested bacteria.

Neither incubation with blocking buffer nor the repeated additions of washing buffer significantly reduced the number of Bodo saltans compared to untreated controls ( $t$-test, $p<0.05$; data not shown) in the test experiment but a small loss (less than $10 \%$ of the flagellate numbers recorded just before the experiments) was found in 2 out of 11 cases.

Immunofluorescence detection of ingested cells: The combined procedures of permeabilization and incubations with antibodies allowed an easy detection of fluorescent-antibody-labelled Pseudomonas fluorescens cells that emitted a bright fluorescence (Fig. 2). After brief uptake periods (less than $15 \mathrm{~min}$ ) the ingested bacterial cells maintained a shape and size comparable to that of labelled bacteria outside the flagellate (Fig. 2A-1). Labelled bacteria were still visible after more than $15 \mathrm{~min}$ but remains of digested bacteria in the food vacuoles did in some cases blur the identification of newly ingested bacteria.

An optical scanning through the flagellates was performed by confocal laser scanning microscopy to verify the intracellular location of the target cells. Concomitant recordings of the fluorescence from antibody-labelled bacteria (Fig. 2A-D) and autofluorescence from the flagellate (Fig. 2E-H) clearly demonstrated the intracellular localization of the ingested bacteria. When all scans were combined into 1 image, the whole flagellate cell, including the 2 flagella, was visible (Fig. 2I).

Uptake experiments: Uptake experiments with 2 single species of heterotrophic nanoflagellates and 1 unidentified species from mixed freshwater culture feeding on Pseudomonas fluorescens ON2 or $P$. putida MM1 showed a linear uptake of FALB during the first approximately $15 \mathrm{~min}$ of the incubation period followed by a steady state in the number of bacterial cells in the food vacuoles (Fig. 3). As degradation of ingested bacteria took place it became more and more difficult to identify newly ingested bacteria as time proceeded.

Spumella sp. feeding on ON2 and MM1 contained 1.5 bacteria flagellate ${ }^{-1}$ as an average

Fig. 2. Microphotographs of an unidentified protist which has ingested a FALB observed by laser confocal scanning microscopy. (A-D) Fluorescence recordings from the antibody-labelled bacteria; $(E-H)$ autofluorescence from the flagellate. The recordings were performed at steps of 0.5 or $1 \mu \mathrm{m}$ from the top to the bottom of the flagellate cell. (I) When all recordings were combined into 1 image the whole flagellate cell appeared
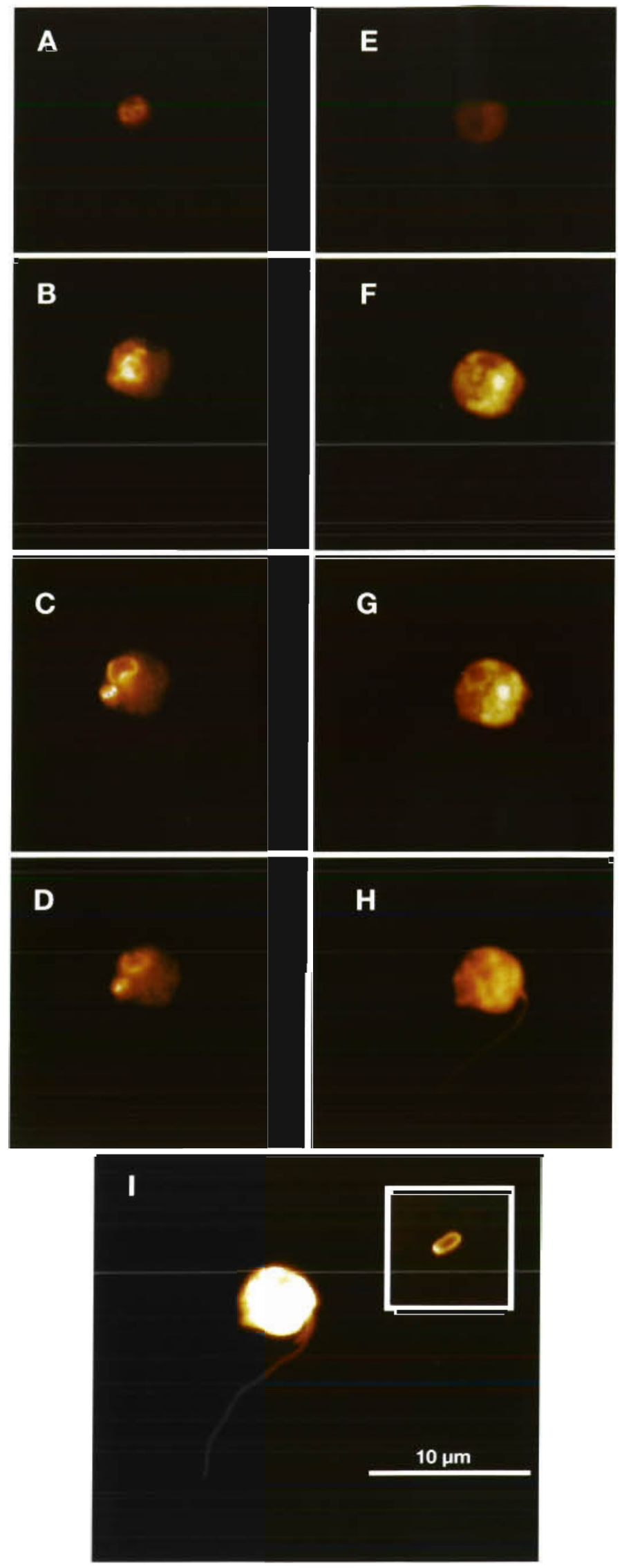

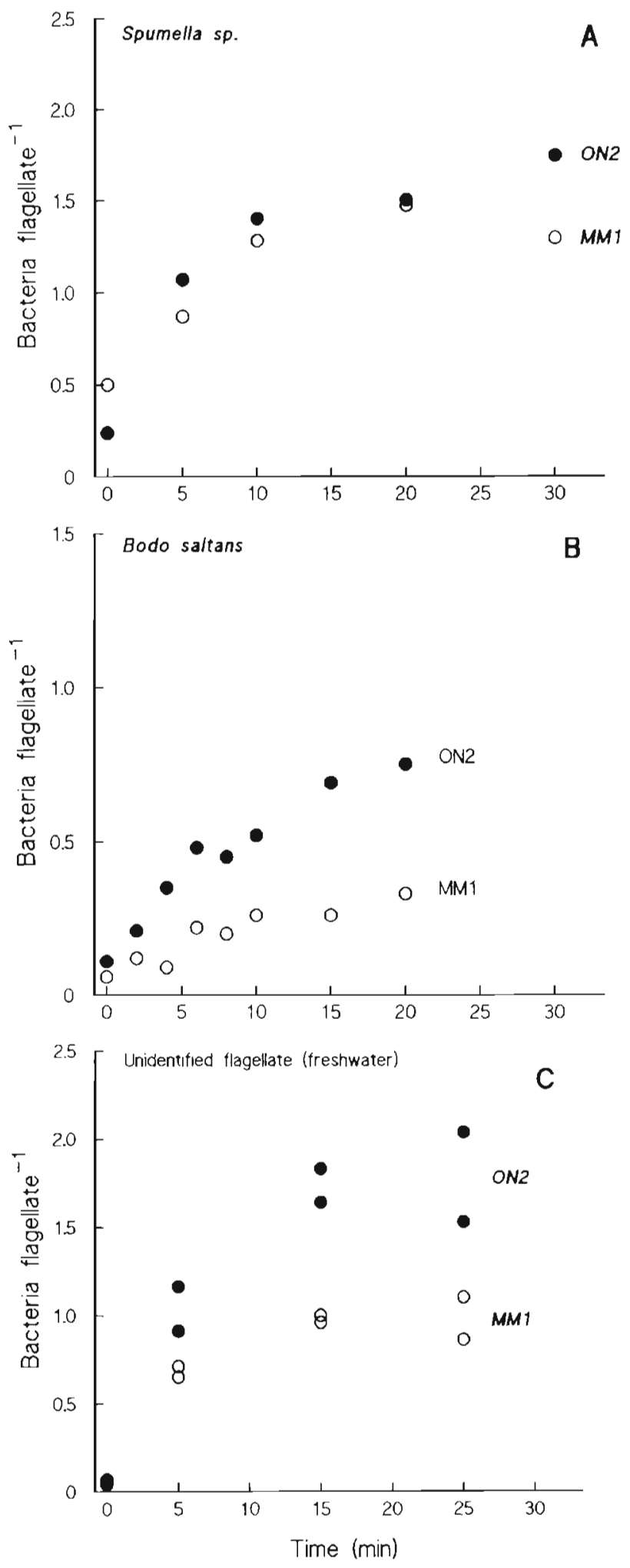

Fig. 3. Time course in feeding activity by (A) Spumella sp. on Pseudomonas fluorescens ON2 and P. putida MM1, (B) Bodo saltans on $P$. fluorescens $O N 2$ and $P$. putida MM1, and (C) an unidentified freshwater heterotrophic nanoflagellate on $P$. fluorescens $\mathrm{ON} 2$ and $P$. putida MM1 saturation maximum whereas the corresponding value for Bodo saltans was 0.7 cells when feeding on ON2 and 0.3 cells when feeding on MM1 (Fig. 3A, B). The unidentified freshwater flagellate contained 1.8 ON2 cells and 1 MM1 cell flagellate-1 (Fig. 3C). Ingestion rates calculated from linear regression of the initial part of the uptake curves ( 0 to $15 \mathrm{~min}$ ) gave approximately 2.5 bacteria (ON2/MM1) ingested $h^{-1}$ for Spumella sp. and $2.2 \mathrm{ON} 2$ and $1.3 \mathrm{MM} 1$ bacteria $\mathrm{h}^{-1}$ for $B$. saltans. The unidentified freshwater flagellate ingested $6.6 \mathrm{ON} 2$ and $3.7 \mathrm{MM} 1$ bacteria $\mathrm{h}^{-1}$. In some cases up to 5 bacteria were contained in a food vacuole. Higher numbers may have occurred but then it was no longer possible to identify individual bacterial cells. A small fraction of flagellates (often less than $10 \%$ ) had not ingested any target bacterial cells.
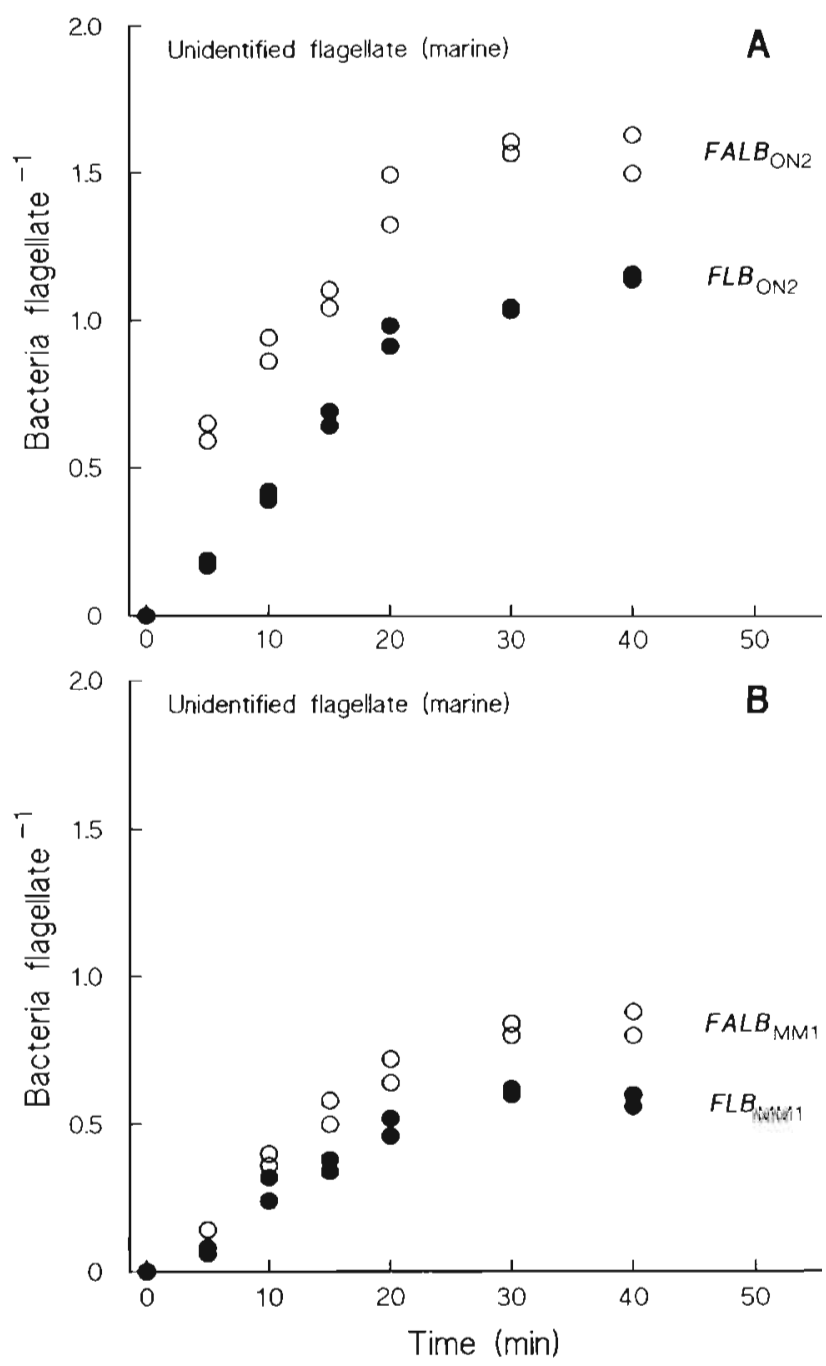

Fig. 4. Time course in feeding activity of an unidentified marine heterotrophic nanoflagellate on (A) Pseudomonas fluorescens ON2 and (B) P. putida MM1 
The unidentified marine nanoflagellate showed comparable trends over time (Fig. 4) and had a clear positive selection for the live bacteria (Pseudomonas fluorescens $\mathrm{ON} 2$ and $P$. putida MM1) compared to the corresponding FLB analogues. The FLBs were 10 to $20 \%$ smaller (data not included) than the live bacteria due to shrinkage during the DTAF labelling procedure. Ingestion rates were 4.1 FALB and 2.1 FLB flagellate ${ }^{-1} \mathrm{~h}^{-1}$ when feeding on ON2, and 2.1 FALB and 1.5 FLB flagellate ${ }^{-1} \mathrm{~h}^{-1}$ when feeding on MM1. Differences in the time course between uptake of FALB and FLB were significant $(t$-test, $\mathrm{p}<0.01)$. Spumella $\mathrm{sp}$. showed a slightly higher ingestion rate of $P$. fluorescens $\mathrm{MM} 1$ compared to $\mathrm{Ag} 1$ in feeding experiments with different ratios of MM1:Ag1 (Fig. 5). Biovolume of individual cells was almost identical

Discussion. Fluorescent antibody techniques are widely used for detection and quantification of different specific types of planktonic microorganisms in aquatic environments (Nybroe et al. 1990, 1992, Campbell et al. 1994, Vrieling et al. 1994, Ahl et al. 1995, Rollo et al. 1995, Zaccone et al. 1995). Furthermore, immunochemical assays have recently been used for qualitative detection of cyanobacteria in the guts of copepods (Goarant et al. 1994) but quantification of the ingested material was not possible.

In the present study the fluorescent antibody technique, using polyclonal antibodies against several Pseudomonas strains, was used to estimate protist grazing on live bacteria. The polyclonal antibodies mediated a distinct and specific recognition of the target bacteria and the ingested bacteria were clearly

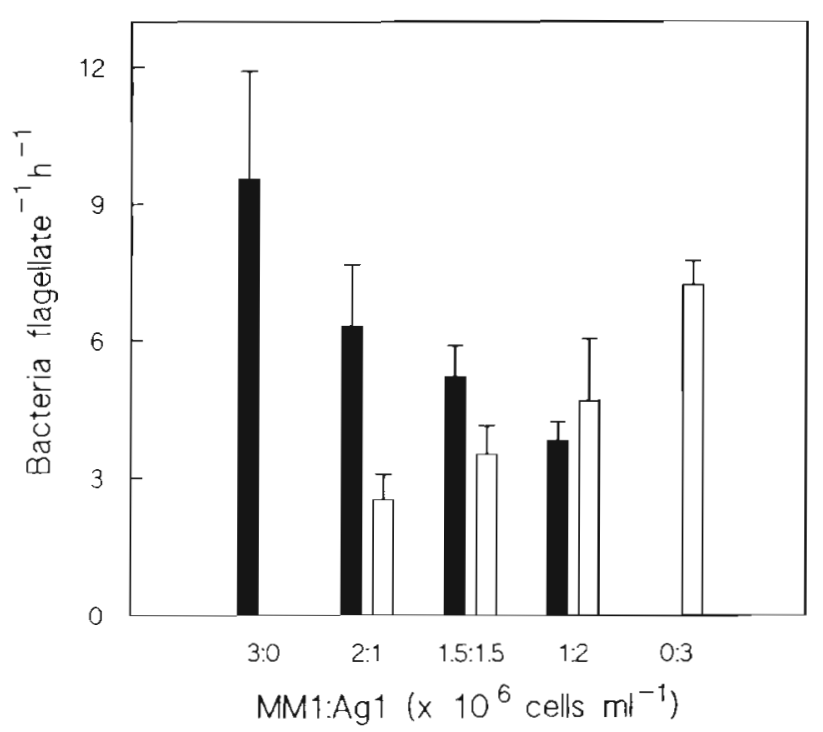

Fig. 5. Ingestion rates of Spumella sp. on Pseudomonas fluorescens strains MM1 and Ag1 added in different ratios. Values are means of triplicate samples and bars are the standard deviation (SD) of the mean visible in the food vacuoles as confirmed by confocal laser scanning microscopy. The food vacuoles were often found in the anterior part of the flagellate (opposite the flagella) close to the cell membrane (an example is presented in Fig. 2).

The immunochemical labelling procedure included permeabilization of fixed flagellate cells with Triton $\mathrm{X}-100$ prior to the immunoreaction. The procedures for permeabilization and immunolabelling were nondestructive to the flagellate cells and it seems that these procedures overcome previously reported cell losses when applying immunofluorescence labelling to phytoplankton (Campbell et al. 1994, Vrieling \& Anderson 1996).

The uptake pattern of Pseudomonas (strains ON2 and MM1) by Spumella sp., Bodo saltans and unidentified freshwater and marine nanoflagellates measured by the new FALB method showed a linear uptake during the first $15 \mathrm{~min}$ during time course experiments (Figs. $3 \& 4$ ). This is consistent with the expected functional feeding response as demonstrated previously using surrogate food cells (e.g. Sherr et al. 1987, González et al. 1990, 1993). Immunolabelled remains of the bacteria were visible inside and around the food vacuoles after feeding times of more than 10 to 15 min, blurring the identification of newly ingested bacteria. Hence, the quick degradation of bacterial cells in the food vacuoles implies that only short-term feeding experiments are possible. A vacuole turnover time of 10 to $15 \mathrm{~min}$ is in accordance with previous reports (e.g. Gonzalez et al. 1993).

Spumella sp., Bodo saltans and an unidentified freshwater flagellate ingested Pseudomonas fluorescens strain $\mathrm{ON} 2\left(0.5 \mathrm{\mu m}^{3}\right)$ with higher efficiency than they ingested strain MM1 $\left(0.5 \mu^{3}\right)$ (Fig. 3). No discrimination was found for Spumella sp. feeding on strains MM1 and Ag1 which were of almost equal size. These findings are in accordance with several previous studies (Chrzanowski \& Simek 1990, González et al. 1990, Simek \& Chrzanowski 1992, Christoffersen et al. 1995).

The feeding activity measured by the FALB method provided ingestion rates of 1 to 7 bacteria flagellate ${ }^{-1}$ $\mathrm{h}^{-1}$ which are consistent with previous studies using heat-killed or live bacteria (Monger \& Landry 1992, Simek \& Chrzanowski 1992, González et al. 1993). The ingestion rates obtained using FALB as food particles were significantly higher than those obtained using FLB. This confirms conclusions from several recent studies using vital stain to determine grazing on bacteria. Landry et al. (1991) showed Paraphysomonas vestita to feed preferentially on rhodamine-isothiocyanate-labelled Escherichia coli compared to feeding on heat-killed $E$. coll and Monger \& Landry (1992) observed the same trend with an unidentified marine 
heterotrophic nanoflagellate feeding on live (fluorescein-isothiocyanate-stained) or heat-killed bacteria isolated from marine waters. Thus, the use of intact food particles such as rhodamine-labelled bacteria or the FALB used in this study seems decisive for reliable feeding experiments although it should be stressed that not all protozoans have strong selective behavior (González et al. 1993).

The method presented here overcomes several limitations inherent in previous methods of estimating protist grazing on bacteria. Most important is that the FALB method is non-destructive to the prey organisms up to the time of analysis and thus measures realistic ingestion rates on specific food particles or selection between food particles. Equally important, immunofluorescence labelling is robust thus eliminating the problems with insufficient labelling of the prey organism as have been observed using vital stains (Epstein \& Rossel 1995).

In conclusion, future studies focusing on selectivity based on prey cell morphology, motility and chemical properties may take advantage of the new FALB method. Recently, it has been shown that the feeding pattern of bacterivorous flagellates is in accordance with optimal diet theory (Jürgens \& DeMott 1995), which predicts that food selectivity increases at higher food concentrations. Future studies may benefit from using live food of similar sizes but different in terms of e.g. nutritional values.

Another aspect is that individual feeding behavior can be studied at a high resolution in time since the detection by antibodies is specific and generally very sensitive. This should allow detection of even small changes in feeding activity as well as larger changes such as diel variation (Christoffersen 1994). It should, however, be kept in mind that the use of the FALB method implies that the prey organism must be added to the grazers and thus change the food concentration (McManus \& Okubo 1991).

Antibodies against a variety of eukaryotes and prokaryotes (Ohman et al. 1991, Ohman 1993, Kragelund et al. 1996, Vrieling \& Anderson 1996) might be useful in future studies addressing in situ interactions between specific grazers and specific prey by immunochemical double labelling techniques. For this type of studies, and for studies of plankton autecology, the application of confocal laser scanning microscopy seems very promising (Verity et al. 1996).

Acknowledgements. We are grateful for the technical assistance of Nils Willumsen and Charlotte Andersen. We thank Jan Sørensen (Royal Veterinary and Agricultural University, Copenhagen) for allowing us to use facilities for confocal laser scanning microscopy. This work was supported by the Danish Science Research Council (contract no. 11-8348), the Danish
Veterinary and Agricultural Research Council (contract no. 13-4898), the Danish Technical Science Research Council (contract no. 16-5232) and the Danish Research Academy (contract no. D930128).

\section{LITERATURE CITED}

Ahl I, Christoffersen K, Riemann B, Nybroe O (1995) A combined microcosm and mesocosm approach to examine factors affecting survival and mortality of Pseudomonas fluorescens Agl in sea water. FEMS Microb Ecol 17: $107-116$

Børsheim KY (1984) Clearance rates of bacteria-sized particles by freshwater ciliates, measured with monodisperse fluorescent latex beads. Oecologia 63:286-288

Campbell L, Shapiro LP, Haugen E (1994) Immunochemical characterization of eukaryotic ultraplankton from the Atlantic and Pacific Oceans. J Plankton Res 16:35-51

Christoffersen K (1994) Variations of feeding activities of heterotrophic nanoflagellates on picoplankton. Mar Microb Food Webs 8:111-123

Christoffersen K, Ahl T, Nybroe O (1995) Grazing on nonindigenous bacteria by nano-sized protozoa in a natural coastal system. Microb Ecol 30:67-78

Chrzanowski TH, Simek K (1990) Prey-size selection by freshwater flagellated protozoa. Limnol Oceanogr 35:1429-1436

Epstein SS, Rossel J (1995) Methodology of in situ grazing experiments: evaluation of a new vital dye for preparation of fluorescently labeled bacteria. Mar Ecol Prog Ser 128: $143-150$

Goarant E, Prensier G, Lair N (1994) Specific immunological probes for the identification and tracing of prey in crustacean gut contents. The example of cyanobacteria. Arch Hydrobiol 131:243-252

González JM, Sherr EB, Sherr BF (1990) Size-selective grazing on bacteria by natural assemblages of estuarine flagellates and ciliates. Appl Environ Microbiol 56:583-589

González JM, Sherr EB, Sherr BF (1993) Differential feeding by marine flagellates on growing versus starving, and on motile versus nonmotile, bacterial prey. Mar Ecol Prog Ser 102:257-267

Johnson GD, de Nogueira Araujo GM (1981) A simple method of reducing the fading of immunofluorescence during microscopy. J Immunol Meth 43:349-350

Jürgens K, DeMott WR (1995) Behavioral flexibility in prey selection by bacterivorous nanoflagellates. Limnol Oceanogr 40:1503-1507

Kragelund L, Leopold K, Nybroe O (1996) Outer membrane heterogeneity within Pseudomonas fluorescens and $P$. putida and the use of an OprF antibody as a probe for rRNA homology group I pseudomonads. Appl Environ Microbiol 62:480-485

Landry MR (1994) Methods and controls for measuring the grazing impact of planktonic protists. Mar Microb Food Webs 8:37-57

Landry MR, Lehner-Fournier JM, Sundstrom JA, Fagerness VL, Selp KE (1991) Discrimination between living and heat-killed prey by a marine zooflagellate, Paraphysomonas vestita (Stokes). J Exp Mar Biol Ecol 146:139-151

McManus GB, Okubo A (1991) On the use of surrogate food particles to measure protistan grazing. Limnol Oceanogr $36: 613-617$

Monger BC, Landry MR (1992) Size-selective grazing by heterotrophic nanoflagellates: an analysis using live-stained bacteria and dual-beam flow cytometry. Arch Hydrobiol Beih 37:173-185 
Nybroe O, Christoffersen K, Riemann B (1992) Survival of Bacillus licheniformis in seawater model ecosystems. Appl Environ Microbiol 58:252-259

Nybroe O, Johansen A, Laake M (1990) Enzyme-linked immunosorbent assays for detection of Pseudomonas fluorescens in sediment samples. Lett Appl Microbiol 11: $293-296$

Ohman MD (1993) Predation on planktonic protists assessed by immunochemical assays. In: Kemp PF, Sherr BF. Sherr EB, Cole JJ (eds) Handbook of methods in aquatic microbial ecology. Lewis Publishers, Boca Raton, p 731-737

Ohman MD. Theilacker GH, Kaupp SE (1991) Immunochemical detection of predation on ciliate protists by larvae of the northern anchovy (Engraulis mordax). Biol Bull (Woods Hole) 181:500-504

Rollo F, Sassaroli S, Boni L, Marota I (1995) Molecular typing of red-tide dinoflagellate Gonyaulax polyedra in phytoplankton suspensions. Aquat Microb Ecol 9:55-61

Sherr BF, Sherr EB, Fallon RD (1987) Use of monodispersed fluorescently labeled bacteria to estimate in situ protozoan bacterivory. Appl Environ Microbiol 53:958-965

Responsible Subject Editor: T. F. Thingstad, Roskilde, Denmark
Sherr EB, Sherr BF (1994) Bacterivory and herbivory: key roles of phagotrophic protists in pelagic food webs. Microb Ecol 28:223-235

Simek K, Chrzanowski TH (1992) Direct and indirect evidence of size-selective grazing on pelagic bacteria by freshwater nanoflagellates. Appl Environ Microbiol 58: 3715-3720

Verity PG, Beatty TM, Williams SC (1996) Visualization and quantification of plankton and detritus using confocal microscopy. Aquat Microb Ecol 10:55-67

Vrieling EG, Anderson DM (1996) Immunofluorescence in phytoplankton research: applications and potential. J Phycol 32:1-16

Vrieling EG, Peperzak L, Gieskes WW, Veenhuis M (1994) Detection of the ichthyotoxic dinoflagellates Gyrodinium (cf.) aureolum and morphologically related Gymnodinium species using monoclonal antibodies: a specific immunological tool. Mar Ecol Prog Ser 103:165-174

Zaccone $R_{r}$ Crisafi $E$, Caruso $G$ (1995) Evaluation of fecal pollution in codstal italian waters by immunofluorescence. Aquat Microb Ecol 9:79-85

Manuscript received: October 25, 1996

Revised version accepted: May 15, 1997 